\title{
Characterization of sunburn damage to apple fruits and leaves
}

\author{
Racskó, J. ${ }^{1}$, Szabó, T. ${ }^{2}$, Nyéki, J. ${ }^{3}$, Soltész, M. ${ }^{4}$, Nagy, P.T. ${ }^{5}$, Miller, D.D. ${ }^{1}$ \& Szabó, Z. ${ }^{3}$ \\ ${ }^{1}$ Department of Horticulture and Crop Science, Ohio Agricultural Research and Development Center, \\ The Ohio State University, 1680 Madison Ave., Wooster, 44691-OH, USA, Email: racsko.1@osu.edu \\ ${ }^{2}$ Research and Extension Station for Fruit Production, 2 Vadas-tag, Újfehértó, 4244, Hungary, \\ Email:szaboti@ujfehertokutato.hu \\ ${ }^{3}$ Institute for Research and Development, University of Debrecen, 138 Böszörményi St., Debrecen, 4032, Hungary, \\ Email: nyeki@agr.unideb.hu \\ ${ }^{4}$ Department of Fruit Production, Faculty of Horticulture, College of Kecskemét, 1-3 Erdei Ferenc square, \\ Kecskemét,6000,Hungary,Email: soltesz.miklos@kfk.kefo.hu \\ ${ }^{5}$ Department of Agricultural Chemistry, University of Debrecen, 138 Böszörményi St., Debrecen, 4032, Hungary, \\ Email:nagypt@agr.unideb.hu
}

Summary: The specific conditions of the formation of three different types of sunburn (sunburn browning, sunburn necrosis, and photooxidative sunburn) have been recently characterized on apple fruit. However, no information is still available on leaf damage. Therefore, the aims of this study were $i$ ) to extend the knowledge on fruit damage, ii) characterize leaf damage and iii) find relationship between fruit and leaf damage. The observations were made on 586 apple accessions in a gene bank orchard located in Hungary. The incidence of the three different types of fruit symptoms were recorded and based on the visual symptoms, two different types of leaf sunburn (sunburn yellowing and sunburn necrosis) were characterized. The most frequent type of fruit sunburn observed was sunburn browning. Photooxidative sunburn was found for less number of accessions, and only some accessions were affected by sunburn necrosis. Fruit were far more susceptible than leaves; $(>60 \%)$ of the examined accessions were affected by fruit damage and $(<3 \%)$ by leaf damage. Although a large number of accessions were affected, the percentage of fruit damaged within accessions was not that excessive; $\sim 6 \%$ of the fruit assessed showed the symptoms of sunburn browning. Significantly fewer fruit were damaged by sunburn necrosis $(\sim 1 \%)$ or photooxidative sunburn $(\sim 1.4 \%)$ than sunburn browning. The percentage of leaves damaged within accessions were simlarly very low $(\sim 1 \%)$. Close relationship between fruit and leaf damage was found. Accesions with relatively heavily sunburned leaves usually had severe fruit damage as well. Leaves showing sunburn symptoms were usually closely located around those fruit which were sunburned severely. Leaf damage of sunburn was found on spur leaves in a great majority of the accessions damaged, shoot leaves did not seem to be susceptible to sunburn.

Key words: apple, Malus domestica, sunburn, sunscald, heat stress, temperature, light stress, spur leaves, shoot leaves

\section{Introduction}

Sunburn is a physiological disorder of apple fruit caused by excessive solar radiation (Barber \& Sharpe, 1971; Schrader et al., 2001, 2003a). It severely affects fruit finish and marketing quality (Racskó et al., 2005b, c; Schrader et al., 2008), and thus causing serious problems in several apple growing regions of the world (Bergh et al., 1980; Simpson et al., 1988; Warner, 1997). Sunburn costs the apple industry hundreds of millions of dollars annually. For instance, in Washington State, which produces over half of the U.S. apple crop, sunburn is usually the major source of cullage with losses averaging 10\% annually (Racskó et al., 2005a; Schrader et al., 2008). In warmer climates such as South Africa (Bergh et al., 1980; Wand \& Gindaba, 2005), Chile (Yuri et al., 1996) and Australia (Middleton et al., 2002; Mackay, 2009), losses can often be even three or four times higher than in Washington State.

The fact that besides apples, sunburn can damage several other species of fruits and also vegetables, points to its importance. Sunburn damage has been reported in pears (Wand et al., 2005; Holmes et al., 2009), bananas (Wade et al., 1993), oranges (Ketchie \& Ballard, 1968), plums (Maxie \& Claypool, 1956), peaches (Moore \& Rogers, 1943), pomegranates (Melgarejo et al., 2004), strawberries (Chesness \& Braud, 1970), blueberries (Caruso, 1995), persimmons (George et al., 1997), pineapples (Keetch, 1977), avocadoes (Schroeder \& Kay, 1961); grapes (Rhoads, 1924; Vanek \& Szöke, 1998); tomatoes (Kedar \& Retig, 1967), peppers (Rabinowitch et al., 1986), cucurbits (Rabinowitch et al., 1986), cabbages (Ramsey et al., 1938), onions (Ramsey \& Wiant, 1941) and beans (Ramsey \& Wiant, 1941). Although sunburn damage has been reported in a wide range of plants, much more is known about sunburn on apples than in other species.

Based on the environmental conditions of the formation of the symptoms, there are three different types of sunburn distinguished in apple fruit; sunburn necrosis, sunburn browning and photooxidative sunburn. The specific 
conditions at which sunburn necrosis and sunburn browning occur were defined by Schrader et al. (2001, 2003b), and the conditions of the formation of photooxidative sunburn have been just recently determined by Felicetti (2003) and Felicetti \& Schrader (2008). The first type, sunburn necrosis, appears after high $\left(\sim 52^{\circ} \mathrm{C}\right)$ fruit surface temperatures (FSTs) causing thermal cell death with complete inactivation of the photosynthetic system. Symptoms occur within 1-4 days after irradiation as dark brown or blackish, necrotic spots on the fruit surface exposed to the sun. The second type, called sunburn browning, is caused by concomitant exposure to high FST (45 to $49^{\circ} \mathrm{C}$ depending on cultivar) and UV-B radiation. In this case, the excess solar energy results in degradation of the pigmentation in the affected area, but does not result in cell death. Sunburn browning usually has symptoms with yellow, brown or dark tan discoloration on the exposed side of the fruit. The third type, photooxidative sunburn, is distinctly different from sunburn necrosis and sunburn browning due to the special conditions of its formation. It requires only visible light and affects shaded (non-acclimated) apples that are suddenly exposed to solar radiation. The initial symptoms of photooxidative sunburn can develop under $31^{\circ} \mathrm{C}$ FST and can be detected within 24 hours as bleaching or whitening of the sun-exposed skin surface. With continued exposure to sunlight, the photobleached area can easily turn brown and cells become necrotic.

As the specific conditions of the formation of each fruit sunburn type have been determined just recently, very little information is available in the literature. Therefore one of the aims of this study was to extend our knowledge on the fruit symptoms of apple sunburn. Since there is no information available so far on leaf symptoms of sunburn, we also aimed to characterize leaf damage and find relationship between fruit and leaf damage.

\section{Materials and methods}

\section{Experimental site and plant material}

Field observations were made in an apple gene bank orchard of the Research and Extension Station for Fruit Growing at Újfehértó, Hungary. The gene bank consists of 586 domesticated apple accessions from throughout the world representing a wide genetic diversity of the Malus domestica species. A great majority of these accessions have been commercially grown cultivars. Examples will be given from cultivars in this paper. The list of the accessions examined is available online at the homepage of the Research and Extension Station for Fruit Growing (http://www. ujfehertokutato.hu). Trees were grafted onto MM.106 rootstock and planted in 1982 (545 accessions) at a spacing of $8 \times 4 \mathrm{~m}$ and trained as central leader. In 1994, additional 41 newly bred cultivars were planted using the same rootstock, tree density, and training system. By the time of evaluation, all trees were in the same size of canopy, with a distance between adjacent canopies within the rows of about $1 \mathrm{~m}$, and an average canopy height of 3-4 $\mathrm{m}$. All trees were planted in N-S row orientation with 2 trees per accession replication, in total 1,172 trees. In the orchard, standard cultural practices (plant protection, winter pruning and fertilization) were followed based on local recommendations, irrigation was not applied. No growing practices influencing the susceptibility of accessions to fruit/leaf sunburn, such as summer pruning, fruit thinning, etc., were applied.

\section{Sunburn assessments}

Sunburn assessments were done on all the 586 accessions during 2 consecutive years, in 2006 and 2007. $4 \times 30=120$ fruit per accession were randomly selected on the tree and assessed in the field at full maturation of fruit. For sunburn assessments, fruit were sorted into four classes; one class was for undamaged fruit showing no symptoms of excessive solar radiation, and three classes for the three different types of sunburn damage according to the Schrader-McFerson classification (Schrader et al., 2003a): sunburn browning, sunburn necrosis and photooxidative sunburn. Those fruit were considered to be affected by sunburn browning which showed yellow or light brown skin discoloration on the sunexposed side of the fruit. Fruit affected by sunburn necrosis had dark brown or black burned spots, whereas as a result of photobleaching, photooxidative sunburn had symptoms of whitish spots on the fruit surface exposed to the sun. The absolute and relative frequencies of damaged/undamaged fruit were recorded.

Similarly to fruit symptoms, leaf symptoms were also assessed. $4 \times 30=120$ leaves per accession were randomly selected on the tree and assessed in the field at the same time as fruit assessments. Since sunburn symptoms on apple leaves have not been reported or described in the literature so far, authors classified the damage oserved based on the visual symptoms. Undamaged, sunburn yellowing and sunburn necrosis categories were distinguished. Photo examples for both types of sunburn symptoms on leaves are shown on Fig. 1. Undamaged leaves showed no symptoms of excessive solar radiation. Leaves affected by sunburn yellowing showed yellow discoloration on the dorsal side of the leaves while brown necrosis on both dorsal and ventral sides of the leaves was observed by sunburn necrosis. The absolute and relative frequencies of damaged/undamaged leaves were recorded. Records were kept on the types of leaves; i.e. spur leaves or shoot leaves, affected by sunburn. Relationship was established between sunburn incidence on leaves and sunburn incidence on fruit.

\section{Data analyses}

Data analysis for sunburn susceptibility of the 586 accessions was performed using SAS for Windows (Release 9.1., SAS Institute Inc., Cary, NC, USA). Statistical significance was defined at $p<0.05$ level. The significance 
of the difference in the ratio of fruit/leaf damaged between 2006 and 2007 was determined using PROC TTEST procedure of SAS. The same procedure was used to establish the difference in the ratio of fruit/leaves damaged between sunburn types. Linear regression analyses were performed for both years (2006 and 2007) using the PROC GLM procedure of SAS. For these analyses, the independent variable was the sunburn incidence to fruit, and the dependent variable was the sunburn incidence to leaves. For the regression analyses, significance of the model was determined by the F-value. Equations and R-square values are also reported.

\section{Results and discussion}

In 2006, 350 accessions showed fruit symptoms of sunburn and 382 in 2007. This represents 59.7\% in 2006 and $65.2 \%$ in 2007, of all the examined 586 accessions. The most frequent type of fruit sunburn observed was sunburn browning; 336 accessions in 2006 and 363 in 2007 were damaged (Fig. 2). Photooxidative sunburn was found for less accessions; 120 and 98 showed symptoms in 2006 and 2007, respectively. Only 37 accessions had sunburn necrosis in 2006 and 45 in 2007. The number of accessions showing leaf damage was far less than those with fruit damage; only 28 accessions out of the 586 were affected in 2006 and 32 in 2007 (Fig. 3).

Although a large number of accessions was affected, the percentage of fruit damaged within accessions was not that excessive; 6.15 and $6.53 \%$ of the fruit assessed showed the symptoms of sunburn browning in 2006 and 2007, respectively (Fig. 4). Significantly fewer fruit were damaged in both years by sunburn necrosis $(1.11 \%$ in 2006 and $1.2 \%$ in 2007) or photooxidative sunburn (1.67\% in 2006 and $1.07 \%$ in 2007) than sunburn browning. Significant difference was found between years for photooxidative sunburn only. The percentage of leaves damaged within accessions were similarly very little; 0.87 and $1.13 \%$ were observed for sunburn yellowing in 2006 and 2007, respectively (Fig. 5). Leaf symptoms of sunburn necrosis were found in $0.29 \%$ (2006) and 0.3\% (2007). Significant differences were not found between years but between sunburn types in both years. Close relationship between fruit and leaf damage was found (Fig. 6). Accesions with relatively heavily sunburned leaves usually had severe fruit damage as well. Leaves showing sunburn symptoms were usually closely located around those fruit which were sunburned severely.

Leaf damage of sunburn was found on spur leaves (32 accessions in 2006 and 28 accessions in 2007) in a great majority of the accessions damaged, shoot leaves (14 accessions in 2006 and 13 in 2007) did not seem to be susceptible to sunburn (Fig. 7). The percentage of leaves damaged was very little compared to fruit damage; $1.19 \%$ of the spur leaves showed the symptoms of sunburn yellowing and $0.82 \%$ sunburn necrosis (Fig. 8). Shoot leaves had sunburn yellowing in $0.32 \%$ and sunburn necrosis in $0.11 \%$ frequency. Sunburn damage on leaves was related neither to ripening time of fruit $\left(\mathrm{R}^{2}\right.$ 2006(linear) $=0.0432 ; \mathrm{R}^{2}{ }_{2007 \text { (linear) }}=$ $0.0061)$ nor individual leaf size $\left(\mathrm{R}^{2}\right.$ 2006(linear) $=0.0127$; $\mathrm{R}^{2}{ }_{2007 \text { (linear) }}=0.0031$ ) of accessions.

Visual symptoms of sunburn was not observed on the epidermis of young shoots or on the bark of branches, regardless of the susceptibility of accessions either to leaf or fruit damage.

Present study prove that excessive solar radiation, besides apple fruit, may damage leaves as well. As leaf symptoms of sunburn in apple have not been characterized yet, authors classified the damage observed based on visual symptoms. Sunburn yellowing and sunburn necrosis categories were distinguished with yellow and dark brown discoloration on the exposed part of leaves, respectively (see Fig. 1). Leaves affected by sunburn yellowing showed yellow discoloration on the dorsal side of the leaves while brown necrosis on both dorsal and ventral sides of the leaves was observed by sunburn necrosis. Similarly to fruit symptoms, it is assumed that sunburn yellowing is a result of a particular combination of excessive heat and UV-B radiation, while sunburn necrosis is likely a simple thermal cell death caused by excessive heat only. As the pigments of green cultivars are chlorophyll similarly to leaf pigments, and they show the symptoms of sunburn browning, sunburn necrosis, or even photooxidative sunburn in certain environmental conditions, leaves might behave the same way showing these symptoms in similar light and temperature environments. This theory is supported by the observation that sunburn yellowing on leaves was found around those fruit which had sunburn browning, i.e. exposed to high temperature and UV-B radiation. Sunburn necrosis on leaves was almost obligatory around those fruit which had solely symptoms of sunburn necrosis, i.e. exposed to excessive heat only. However, the threshold temperatures for leaf damage should be higher than that for fruit damage as the percentage of leaves damaged were far less than that of fruit. Here the resistance of the leaves to sunburn may simply be due to the thin leaf dissipating the energy it absorbs more effectively than a large fruit can (Barber \& Sharpe, 1971). The leaf cools itself by evaporation of water and by convection of heat to the surrounding atmosphere more effectively than is the case with a large fruit, in which stomata are often relatively few or completely absent (Clendenning, 1941). Furthermore, leaves have a much higher capacity for photosynthesis than do fruits, and therefore it is expected that there is less excess absorbed photon flux density (PFD) and a lesser need to dissipate the excess excitation energy ( $M a \&$ Cheng, 2003). Further work is required to determine the specific conditions of the formation of sunburn symptoms on apple leaves and confirm above theory.

In this study, sunburn damage was found mostly for spur leaves rather than shoot leaves. This is in an apparent contradiction with their position; shoot leaves are in a much higher exposition compared to spur leaves. However, the possible explanaition for the higher damage to spur leaves 
can be found in the environmental conditions in which they form. Spur leaves develop first in the spring in a relatively cool and humid environment, whereas shoot leaves continuously later in the season during the summer. This assumes a higher level of acclimation/tolerance of shoot leaves to higher temperatres/light environments than spur leaves.

Besides sunburn yellowing and sunburn necrosis, a possible ,third type” of leaf symptoms, similarly to the fruit symptom called photooxidative sunburn, may exist and likely caused by sudden exposure of leaves to direct radiation causing whitish bleaching symptoms. In this study, authors did not observe such symptoms as growing practices influencing the susceptibility of accessions to sunburn, such as summer pruning, were not applied in the gene bank orchard neither in 2006 nor in 2007. The existence is most likely as similar symptoms, i.e. whitish patches on the leaves after sudden exposure to strong irradiation, have already been reported from other plants (Nigam, 1934) and referred to as sun scorch. To prove the existence of such a ,third type" of sunburn on apple leaves also needs further study.

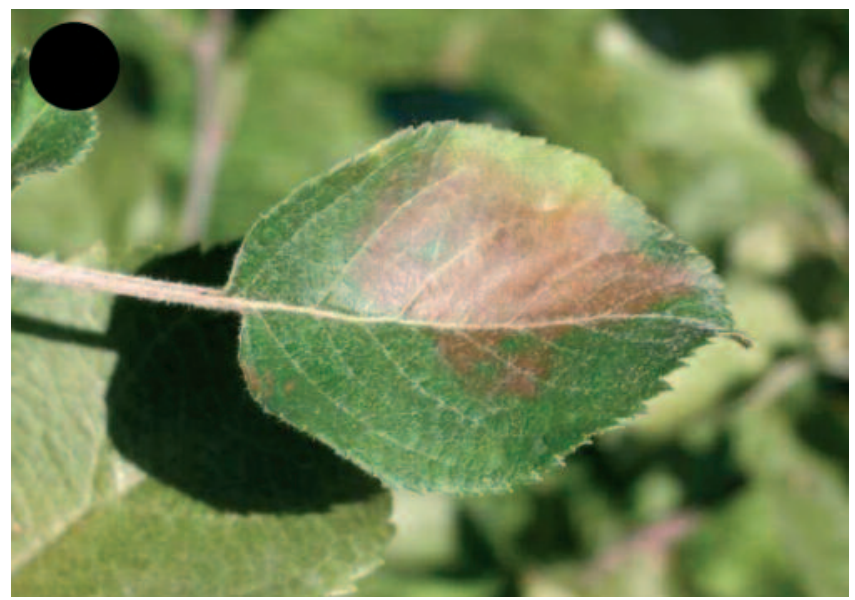

Figure 1. Examples for the two types of sunburn symptoms observed on apple leaves: A - sunburn yellowing ('Remo'); and B - sunburn necrosis ('Delor'). Note that generally spur leaves are affected.

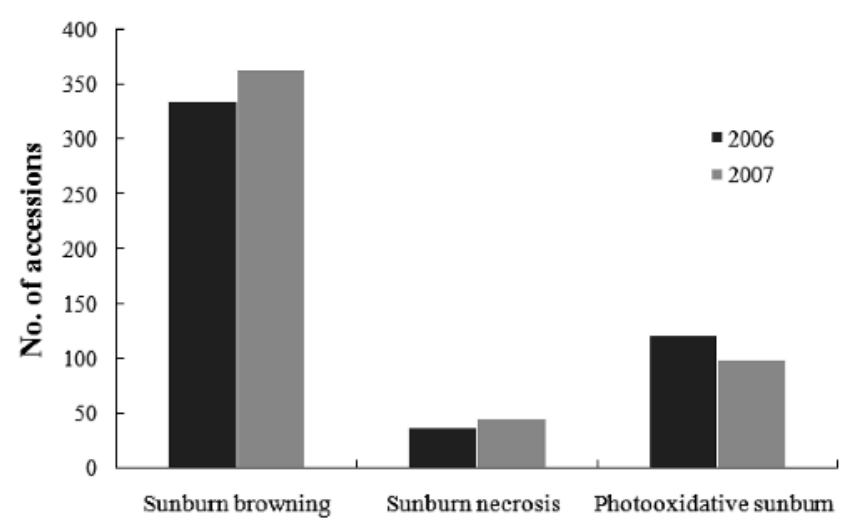

Figure 2. Number of accessions showed fruit symptoms of the three types of apple sunburn from the examined 586 accessions. Several accessions showed the symptoms of two or even all the three types of sunburn in the same year; thus the sum of the accessions in the three types is not equal to the number of accessions damaged

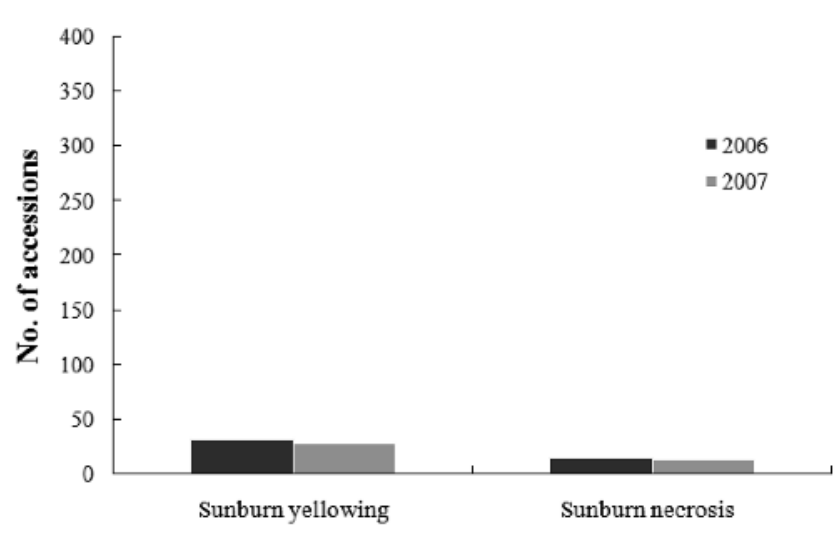

Figure 3. Number of accessions showed leaf symptoms of the two types of sunburn from the examined 586 accessions. Several accessions showed the symptoms of two types of sunburn in the same year; thus the sum of the accessions in the three types is not equal to the number of accessions damaged.

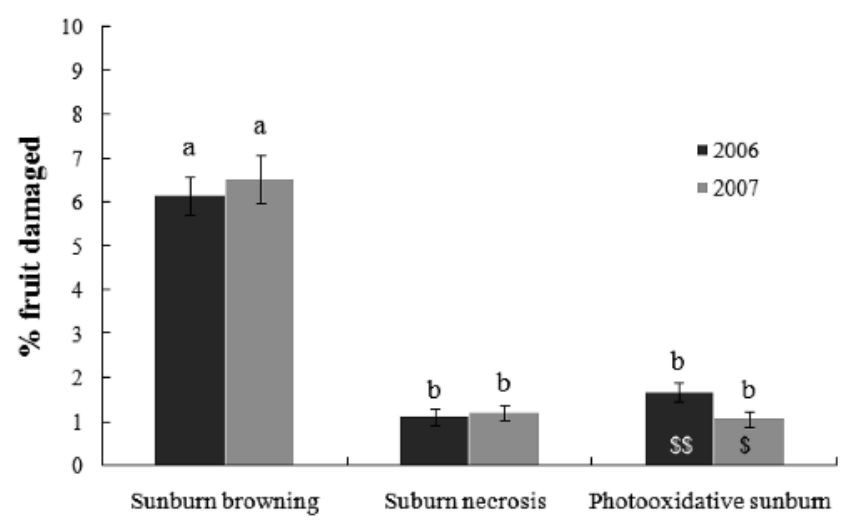

Figure 4. Percentage ( \pm S.D.) of fruit within accessions showed the symptoms of the three types of apple sunburn. Sunburn browning: $\mathrm{N}_{2006}=$ $336, \mathrm{~N}_{2007}=363$; sunburn necrosis: $\mathrm{N}_{2006}=37, \mathrm{~N}_{2007}=45$; and photooxidative sunburn: $\mathrm{N}_{2006}=120, \mathrm{~N}_{2007}=98$. Different letters above columns represent significant differences between sunburn types within years at $\mathrm{P}<0.05$ level. Different characters within columns represent significant differences between years within sunburn types at $\mathrm{P}<0.05$ level.

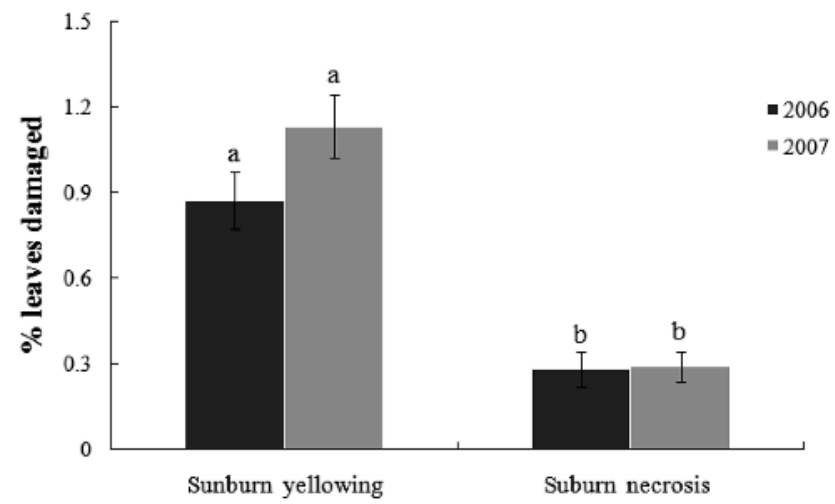

Figure 5. Percentage ( \pm S.D.) of leaves within accessions showed the symptoms of the two types of sunburn. Sunburn yellowing: $\mathrm{N}_{2006}=28$, $\mathrm{N}_{2007}=32$; sunburn necrosis: $\mathrm{N}_{2006}=13, \mathrm{~N}_{2007}=13$. Different letters above columns represent significant differences between sunburn types within years at $\mathrm{P}<0.05$ level. Significant differences between years within sunburn types were not found. 


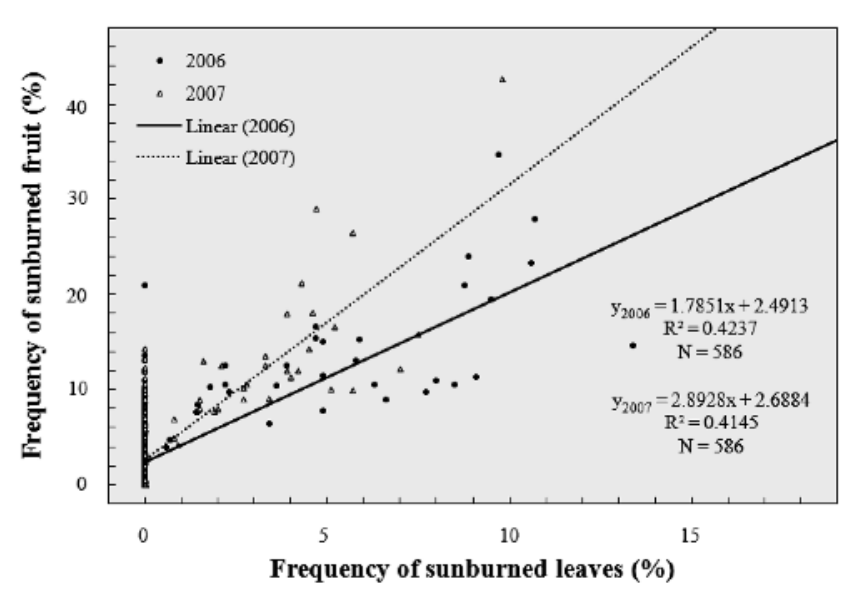

Figure 6. Relationship between the frequency of sunburn incidence on fruit and sunburn incidence on leaves. Each mark represents the average value of a particular cultivar/accession (120 fruit) in 2006 and 2007. sunburn in the same year; thus the sum of the accessions in the three types is not equal to the number of accessions damaged.

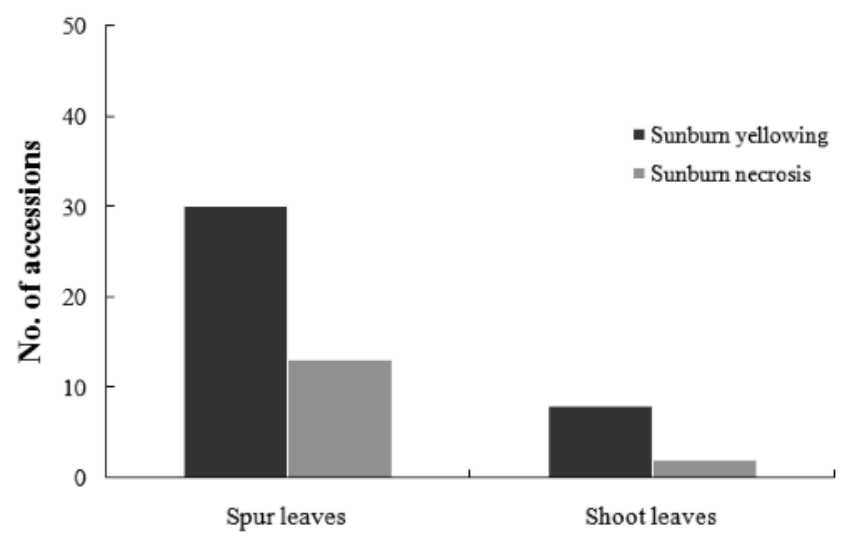

Figure 7. Number of accessions showed the symptoms of sunburn yellowing and sunburn necrosis on spur leaves and shoot leaves in the gene bank of 586 apple accessions. All accessions showed any of the symptoms on shoot leaves had leaf damage on spur leaves at the same time, and all accessions having sunburn necrosis showed the symptoms of sunburn browning, too. Thus the number of accessions damaged is equal to the number of accessions having sunburn yellowing on spur leaves, that is 30. Data are based on the average of 2006 and 2007.

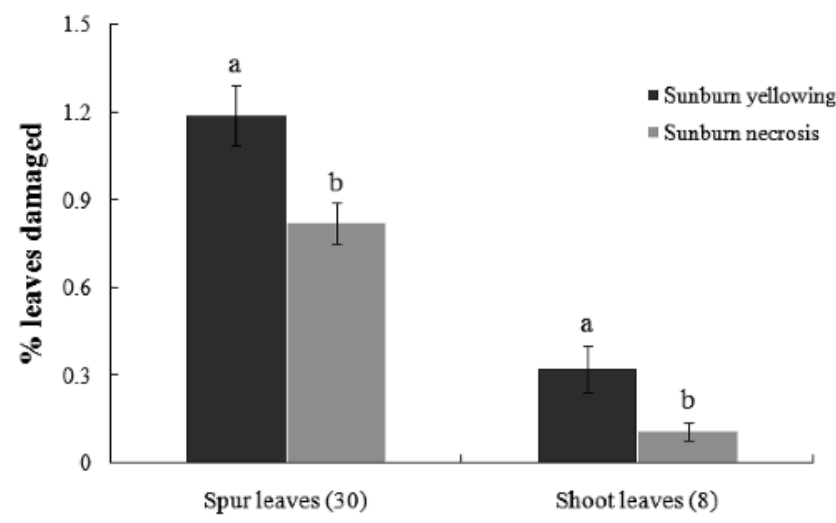

Figure 8. Percentage ( \pm S.D.) of leaves within accessions showed the symptoms of the two types of sunburn on spur and shoot leaves. Numbers in parentheses represent the number of accessions that had sunburn damage on the two types of leaves. Different letters above represent significant differences between sunburn types at $\mathrm{P}<0.05$ level.

\section{References}

Barber, H.N. \& Sharpe, P.J.H. (1971): Genetics and physiology of sunscald of fruits, Agric. Met. 8: 175-191.

Bergh, O., Franken, J., Zyl, E.J., van Kloppers, F. \& Dempers, A. (1980): Sunburn on apples - Preliminary results of an investigation conducted during the 1978/79 season, Deciduous Fruit Grower 30: 8-22.

Caruso, F.L. (ed.) (1995): Compendium of blueberry and cranberry diseases. Amer. Phytopath. Soc., St. Paul.

Chesness, J.L. \& Braud, H.J. (1970): Sprinkling to reduce heat stressing of strawberry plants. Agric. Engineering 51: 140-141.

Clendenning, K.A. (1941): Studies of the tomato in relation to its storage. II. The effects of altered internal atmosphere upon the respiratory and ripening behaviour of tomato fruits stored at $12.5 \mathrm{C}$. Can. J. Res., Sect. C. 19: 500-518.

Felicetti, D.A. (2003): Characterization of a third type of apple sunburn caused by sudden exposure of shaded apples to sunlight. M.S. Thesis, Washington State University, Pullman. 28. pp.

Felicetti, D.A. \& Schrader, L.E. (2008): Photooxidative sunburn of apples: Characterization of a third type of apple sunburn. Int. J. Fruit Sci. 8, (3): 160-172.

George, A.P, Collins, R.J., Mowat, A.D. \& Subhadrabandhu, S. (1997): Factors affecting blemishing of persimmon in New Zealand and Australia. Acta Hort. 436: 171-177.

Holmes, R., Crisera, M. \& Brown, G. (2009): Harvest and postharvest options for heat-affected apples and pears. Australian Fruitgrower 3, (2): 8-10.

Kedar, N. \& Retig, N. (1967): An oblong dwarf tomato resists sunscald. New Scientist 36: 546.

Keetch, D.P. (1977): Sunburn in pineapples. Farming in South Africa, Pineapple Series No. H.8/1977, 4 pp.

Ketchie, D.O. \& Ballard, A.L. (1968): Environments which cause heat injury to 'Valencia' oranges. Proc. Am. Soc. Hort. Sci. 93: 166-172.

Ma, F. \& Cheng, L. (2003): The sun-exposed peel of apple fruit has higher xanthophyll cycle-dependent thermal dissipation and antioxidants of the ascorbate-glutathione pathway than the shaded peel. Plant Sci. 165: 819-827.

Mackay, K. (2009): Reduce sun damage. Tree Fruit, September: 19.

Maxie, E.C. \& Claypool, L.L. (1956): Heat injury in prunes. Proc. Am. Soc. Hort. Sci. 69: 116-121.

Melgarejo, P., Martínez, J.J., Hernández, F., Martínez-Font, R., Barrows, P. \& Erez, A. (2004): Kaolin treatment to reduce pomegranate sunburn. Sci. Hortic. 100: 349-353.

Middleton, S., McWaters, A., James, P., Jotic, P., Sutton, J. \& Campbell, J. (2002): The productivity and performance of apple orchard systems in Australia. Compact Fruit Tree 35, (2): 43-47.

Moore, M.H. \& Rogers, W.S. (1943): Sun scald of fruits. Rep. East Malling Res. Sta. for 1942. 50-53.

Nigam, B.S. (1934): Effect of excessive humidity on the resistance of citrus plant to sun scorch. Am. J. Bot. 21, (7): 351-354.

Rabinowitch, H.D., Ben-David, B. \& Friedmann, M. (1986): Light is essential for sunscald induction in cucumber and pepper fruits, whereas heat conditioning provides protection. Scientia Hort. 29: 21-29.

Racskó, J., Nagy, J., Szabó, Z., Major, M. \& Nyéki, J. (2005a): The impact of location, row direction, plant density and rootstock on the sunburn damage of apple cultivars. Int. J. Hort. Sci. 11, (1): 19-30. 
Racskó, J., Szabó, Z. \& Nyéki, J. (2005b): Importance of the supraoptimal radiance supply and sunburn effects on apple fruit quality. Acta Biol. Szegediensis 49: 111-114.

Racskó, J., Thurzó, S., Szabó, Z. \& Nyéki, J. (2005c): Schadwirkung des Sonnenbrands auf das Gewebe des Apfels (Malus domestica Borkh.) [Effect of sunburn on Malus domestica Borkh. apples]. Gesunde Pflanzen 57, (2-3): 47-52. (In German with English Summary)

Ramsey, G.B. \& Wiant. J.S. (1941): Market diseases of fruits and vegetables: asparagus, onions, beans, peas, carrots, celery, and related vegetables. U.S. Dept. Agr., Misc. publ. 440: 17-32.

Ramsey, G.B., Wiant, J.S. \& Link, G.K.K. (1938): Market diseases of fruits and vegetables: Crucifers and cucurbits. U.S. Dept. Agr., Misc. publ. 292: 20.

Rhoads, A.S. (1924): Sun-scald of grapes and its relation to summer pruning. Amer. Fruit Grower 44, (3): 20-47.

SAS Institute Inc. (2002-2003): SAS Procedures Guide, Version 9.1.Cary, NC, USA.

Schrader, L.E., Zhang, J. \& Duplaga, W.K. (2001): Two types of sunburn in apple caused by high surface (peel) temperature. Plant Health Progress, online doi:10.1094/PHP-2001-1004-01-RS.

Schrader, L.E., Sun, J., Felicetti, D., Seo, J-H., Jedlow, L. \& Zhang, J. (2003): Stress-induced disorders: effects on apple fruit quality. Washington Tree Fruit Postharvest Conf., Wenatchee, WA. 7. pp. Online at http://postharvest.tfrec.wsu.edu/PC2003A.pdf

Schrader, L.E., Zhang, J. \& Sun, J. (2003b): Environmental stresses that cause sunburn of apple. Acta Hort. 618: 397-405.

Schrader, L.E., Sun, J., Zhang, J., Felicetti, D.A. \& Tian, J.
(2008): Heat and light induced apple skin disorders: causes and prevention. Acta Hort. 772: 51-58.

Schroeder, C.A. \& Kay, E. (1961): Temperature conditions and tolerance of avocado fruit tissue. Calif. Avocado Soc. Yearbook 45: 87-92.

Simpson, J., Rom, C.R. \& Patterson, M. (1988): Causes and possible controls of sunburn on apples. Good Fruit Grower 39, (2): $16-17$.

Vanek, G. \& Szőke, L. (1998): Napperzselés (infravörös sugárzás) és a napsugárzás (UV sugárzás) tünetei szőlőn [Symptoms of sunburn (infrared radiation) and solar irradiation (UV radiaition) on grapes]. Integrált Termesztés a Kertészetben 19: 71-76. (In Hungarian)

Wade, N.L., Kavanagh, E.E. \& Tan, S.C. (1993): Sunscald and ultraviolet light injury of banana fruits. J. Hort. Sci. 68, (3): 409-419.

Wand. S.J.E. \& Gindaba, J. (2005): Controlling sunburn: What are the options? South African Fruit Journal Oct/Nov: 24-26.

Wand, S.J.E., Steyn, W.J., Holcroft, D.M., Mdluli, M.J., van den Dool, K. \& Jacobs, G. (2005): Use of evaporative cooling to improve 'Rosemarie' and 'Forelle' pear fruit blush colour and quality. Acta Hort. 671: 103-111.

Warner, G. (1997): Sunburn is a hot topic in orchards of Washington. Good Fruit Grower 48: 22-23.

Yuri, J.A., Torres, C., Vázquez, J. \& Vázquez, J.L. (1996): Golpe de sol. La Experiencia Chileana, 75-101, In: Yuri, J.A., Moggia, C., Torres, C. (eds.). Coloquio en Pomáceas: Golpe de sol, machucón, escaldado. Centro de Pomáceas. Univ. de Talca. 101. p. 